\title{
Profile of gantenerumab and its potential in the treatment of Alzheimer's disease [Corrigendum]
}

\author{
Novakovic D, Feligioni M, Scaccianoce S, et al. Drug Des \\ Devel Ther. 2013;7:1359-1364.
}

On page 1362, left hand column, last sentence under Functional studies:

The effects of gantenerumab on cognitive assessment in the Morris water maze test were inconclusive, as both wild-type and transgenic $\mathrm{AD}$ mice injected with vehicle displayed impairment of learning, which might be ascribed to stress conditions caused by weekly intracerebroventricular injections. Importantly, neurological or motor impairments were not detected even after 5 months of treatment. ${ }^{24}$

Should read as:

The effects of gantenerumab on cognitive assessment in the Morris water maze test were inconclusive, as both wild-type and transgenic $\mathrm{AD}$ mice injected with vehicle displayed impairment of learning, which might be ascribed to stress conditions caused by weekly intravenous injections. Importantly, neurological or motor impairments were not detected even after 5 months of treatment. ${ }^{24}$

\section{Publish your work in this journal}

Drug Design, Development and Therapy is an international, peerreviewed open-access journal that spans the spectrum of drug design and development through to clinical applications. Clinical outcomes, patient safety, and programs for the development and effective, safe, and sustained use of medicines are a feature of the journal, which has also been accepted for indexing on PubMed Central. The manuscript management system is completely online and includes a very quick and fair peer-review system, which is all easy to use. Visit http://www.dovepress.com/testimonials.php to read real quotes from published authors.

Submit your manuscript here: http://www.dovepress.com/drug-design-development-and-therapy-journal

submit your manuscript $\mid$ www.dovepress.com

Dovepress

http://dx.doi.org/10.2147/DDDT.S58818 